\title{
Awareness regarding cardiac rehabilitation among patients with coronary heart disease attending a cardiac care centre, Kathmandu valley
}

\author{
Rosy Shrestha ${ }^{1}$, Sajeeb Shrestha ${ }^{2}$ \\ ${ }^{1}$ School of nursing, Chitwan medical college, Bharatpur, Nepal \\ ${ }^{2}$ Department of public health, Central institute of science and technology, Kathmandu \\ Corresponding Author: Rosy Shrestha \\ School of nursing, Chitwan medical college, Bharatpur, Nepal \\ Email address: rosyshrestha2016@gmail.com
}

Cite this article as: Shrestha R, Shrestha S. Awareness regarding cardiac rehabilitation among patients with coronary heart disease attending a cardiac care centre, Kathmandu valley. Nepalese Heart Journal 2019; Vol 16(1), 47-50

Received date: 22nd March 2019

Accepted date: 16th April 2019

Abstract

Introduction: Coronary heart disease (CHD) is gradually emerging as a leading cause of morbidity and mortality of many low middle income countries like Nepal. Cardiac rehabilitation awareness program has been proved to be effective for reducing the mortality as well as improving the quality of life among CHD patients. The aim of this study was to explore the awareness on cardiac rehabilitation (CR) in patients with CHD attending a cardiac care centre, Nepal.

Method: A descriptive cross sectional study design was used to examine 100 CHD patients attending out-patient departments of Shahid Gangalal National Heart Centre (SGNHC), Kathmandu, Nepal. Purposive sampling technique was used for data collection by face to face interview technique with self developed tool. Data was analyzed with descriptive and inferential statistics.

Results: Of all 100 respondents, $55.0 \%$ were male and the mean age was $53.23 \pm 14.22$ years. The median score of awareness was 17 with interquartile range (IQR) 14.0-19.75 and majority (57.0\%) of respondents were unaware about $\mathrm{CR}$. The awareness regarding CR was found highest in awareness regarding CHD (75.0\%) whereas lowest score was found in time and duration needed for exercise per week (14.0\%). The significant influencing variables were age, education status, duration of treatment and participation in CR program for CHD patients.

Conclusion: The awareness on CR program in CHD patients in Nepal is not optimal, especially among 54 and above age group, illiterate people, those receiving treatment equal \& more than 1 year duration and the CHD patients who didn't get chance to participate on awareness programs. Hence, it is strongly recommended that health professionals including nurses should organize and promote CR programs including counseling session to improve the awareness level and ultimately enhance quality of life of CHD patients.

Key words: Awareness, Cardiac Rehabilitation, Coronary heart disease

DOI: https://doi.org/10.3126/njh.v16i1.23899

\section{Introduction}

Coronary heart disease (CHD) is the leading cause of morbidity \& mortality worldwide, accounting for over onequarter of all deaths in 2001 and in adult population deaths under 65 years $(33 \%))^{1-2}$ And it is forecasted that by $2020 \mathrm{CHD}$ will be a major burden of disease worldwide. ${ }^{3} \mathrm{~A}$ person with CHD presents on a continuum of events that includes angina, myocardial infarction (MI), and ischemic heart failure. ${ }^{4}$ CHD has become a potential time bomb causing deaths in low and middle income countries like Nepal, where preventive measures have not been effective. ${ }^{5}$ It is gradually emerging as one of the major health challenges and prevalence in Eastern region of Nepal was $6 \% .6$ Outpatient and inpatient rehabilitation are an essential part of tertiary prevention for the long-term success of medical treatment and it reduces both cardiovascular and total mortality rates for patients with CHD. It is also reported that $39.0 \%$ of CHD patients had clear indication for rehabilitation for their inpatient hospital stay. ${ }^{7}$ Those who did not undergo rehabilitation were more likely to develop diabetes mellitus, arterial hypertension, or peripheral arterial occlusive disease and had lower left ventricular ejection fractions than those who did undergo rehabilitation. Patients with CHD can benefit from cardiac rehabilitation (CR) programs. ${ }^{8}$ Therefore this study was conducted with the purpose of investigating awareness on cardiac rehabilitation in CHD patients.

\section{Methods}

A descriptive cross-sectional study design was used to examine $100 \mathrm{CHD}$ patients attending outdoor department of Shahid Gangalal National Heart Center (SGNHC), Bansbari, Kathmandu, Nepal during November to December, 2015.. Nonprobability purposive sampling technique was used to select sample, who were clinically diagnosed case of coronary heart disease (Myocardial Infarction, Angina Pectoris and Ischemic heart failure) after angiography for more than three months and subjects with 30 years and above age group were included whereas those who were unable and unwilling to participate

@Nepalese Heart Journal. Nepalese Heart Journal retains copyright and work is simultaneously licensed under Creative Commons Attribution License CC - BY 4.0 that allows others to share the work with an acknowledgement of the work's authorship and initial publication in this journal. 
were excluded from this study. The pretested (Cronbach $\alpha=$ 0.78) tool was used for data collection which consisted three parts: demographic (total items-9) and disease related variables (total items-5) and awareness related cardiac rehabilitation (total items-17). Data was collected by face to face interview schedule at outdoor department of SGNHC, Bansbari, Kathmandu. Ethical clearance was taken from Institutional Review Board (IRB) of Institute of Medicine (IOM), Tribhuvan University, Kathmandu, Nepal. Informed consent (verbal and written as applicable) was obtained from each respondent prior to data collection. Data was analyzed using Statistical Package for the Social Sciences (SPSS) version 20.0. Descriptive (Percentage, frequency, mean and standard deviation, median, interquartile range (IQR) and inferential (Chi-square) statistic was used to find out association between level of awareness and selected variables. The level of awareness was classified into two categories as an aware and unaware based on median value (17) by Shapiro wilk test for normality. The median value of overall awareness was 17 $(57.0 \%)$.

\section{Results}

Table 1 shows that the majority of the respondents were aged $45-59$ years $(34.0 \%)$, male $(55.0 \%)$, resided in urban $(52.0 \%)$, were living with family (76.0\%), Brahmin/Chhetri (59.0), were Hindu (84.0\%), belonged to joint family (51.0), literate (58.0), and housework as an occupation (35.0).

TABLE 1 - Socio-demographic Characteristics of the Respondents

\begin{tabular}{|c|c|}
\hline & $\mathrm{n}=100$ \\
\hline Variables & Frequency/Percent \\
\hline \multicolumn{2}{|l|}{ Age group (in years) } \\
\hline $30-44$ & 29.0 \\
\hline $45-59$ & 34.0 \\
\hline $60-74$ & 26.0 \\
\hline$>74$ & 11.0 \\
\hline \multicolumn{2}{|c|}{ Mean age $\pm S D=53.23 \pm 14.22 ;$ Min $=30 \&$ Max 88 years } \\
\hline \multicolumn{2}{|c|}{ Sex } \\
\hline Male & 55.0 \\
\hline Female & 45.0 \\
\hline \multicolumn{2}{|l|}{ Place of Residence } \\
\hline Rural & 48.0 \\
\hline Urban & 52.0 \\
\hline \multicolumn{2}{|l|}{ Living Status } \\
\hline Living with family & 76.0 \\
\hline Living single & 24.0 \\
\hline \multicolumn{2}{|l|}{ Ethnicity } \\
\hline Brahmin/Chhetri & 59.0 \\
\hline Janajati & 35.0 \\
\hline Dalit & 6.0 \\
\hline \multicolumn{2}{|l|}{ Religion } \\
\hline Hindu & 84.0 \\
\hline Non-Hindu & 16.0 \\
\hline \multicolumn{2}{|l|}{ Type of Family } \\
\hline Nuclear & 49.0 \\
\hline Joint & 51.0 \\
\hline
\end{tabular}

\begin{tabular}{|c|c|}
\hline \multicolumn{2}{|l|}{ Education } \\
\hline Literate & 58.0 \\
\hline Illiterate & 42.0 \\
\hline \multicolumn{2}{|c|}{ Occupation ${ }^{\star}$} \\
\hline Farming & 21.0 \\
\hline Housework & 35.0 \\
\hline Service & 23.0 \\
\hline Business & 21.0 \\
\hline \multicolumn{2}{|c|}{$\begin{array}{l}\text { * Included unmarried, divorced, widower/widow; }{ }^{\star} \text { Included } \\
\text { household activities like cooking, washing, cleaning, etc but do } \\
\text { not earn money }\end{array}$} \\
\hline
\end{tabular}

Table 2 shows that the disease related variables of the respondents. Majority of respondents had diagnosed with Angina Pectoris $(47.0 \%)$ with duration of treatment as 1 year or above $(56.0 \%)$. And majority of respondents were having continuous medical treatment $(51.0 \%)$, presence of comorbidities: hypertension (71.7\%), hyperlipidemia (71.3\%), Diabetes Mellitus $(56.7 \%)$ and respondents who did not get chance to participate in CHD awareness programs $(56.0 \%)$ regarding cardiac rehabilitation.

TABLE 2 - Disease related Variables of the Respondents

\begin{tabular}{|c|c|}
\hline & $\mathrm{n}=100$ \\
\hline Variables & Frequency/Percent \\
\hline \multicolumn{2}{|l|}{ Clinical Diagnosis } \\
\hline Myocardial Infarction & 28.0 \\
\hline Angina Pectoris & 47.0 \\
\hline Ischemic heart failure & 25.0 \\
\hline \multicolumn{2}{|l|}{ Duration of Treatment } \\
\hline$<1$ year & 44.0 \\
\hline$\geq 1$ Years & 56.0 \\
\hline \multicolumn{2}{|l|}{ Mode of Treatment ${ }^{\star}$} \\
\hline $\mathrm{CMT}$ & 51.0 \\
\hline PI & 12.0 \\
\hline CABG & 8.0 \\
\hline $\mathrm{CMT}+\mathrm{PI}$ & 13.0 \\
\hline $\mathrm{CMT}+\mathrm{CABG}$ & 8.0 \\
\hline $\mathrm{CMT}+\mathrm{PI}+\mathrm{CABG}$ & 8.0 \\
\hline \multicolumn{2}{|c|}{ Presence of Comorbidities } \\
\hline Hypertension & 71.7 \\
\hline Hyperlipidemia & 71.3 \\
\hline Diabetes Mellitus & 56.7 \\
\hline \multicolumn{2}{|c|}{ Participated in CR program for CHD patient } \\
\hline Yes & 44.0 \\
\hline No & 56.0 \\
\hline \multicolumn{2}{|c|}{$\begin{array}{l}{ }^{\star} \mathrm{CMT}=\text { Continuous } \mathrm{Medical} \text { Treatment, } \mathrm{PI}=\text { Percutaneous } \\
\text { Intervention and } \mathrm{CABG}=\text { Coronary Artery Bypass Graft }\end{array}$} \\
\hline
\end{tabular}

Table 3 shows awareness scores regarding CR, highest score of the respondents found in awareness regarding CHD (75.0\%) and lowest in time and duration need for exercise per week $(14.0 \%)$. 
TABLE 3 - Awareness Scores Regarding Cardiac Rehabilitation of the Respondents

\begin{tabular}{|c|c|}
\hline & $\mathrm{n}=100$ \\
\hline Knowledge & Frequency/Percent \\
\hline Awareness regarding $\mathrm{CHD}$ & 75.0 \\
\hline Type of CHD & 45.0 \\
\hline Causes of Angina & 35.0 \\
\hline Causes of MI & 44.0 \\
\hline Causes Heart failure & 47.0 \\
\hline Diagnostic measures for CHD & 32.0 \\
\hline Knowledge about stents & 27.0 \\
\hline $\begin{array}{l}\text { Need of cardiac rehabilitation for CHD } \\
\text { patient }\end{array}$ & 58.0 \\
\hline Type of Exercise & 26.0 \\
\hline Time and duration need for exercise/week & 14.0 \\
\hline $\begin{array}{l}\text { Point to be considered before starting } \\
\text { exercise }\end{array}$ & 21.0 \\
\hline Meaning of healthy diet & 63.0 \\
\hline Special point to maintain QOL of patients & 53.0 \\
\hline $\begin{array}{l}\text { Knowledge regarding right time for } \\
\text { resuming duty after CABG }\end{array}$ & 24.0 \\
\hline $\begin{array}{l}\text { Precautions to be taken to avoid } \\
\text { complication }\end{array}$ & 59.0 \\
\hline Management of emergency conditions & 49.0 \\
\hline Complication of CHD & 53.0 \\
\hline
\end{tabular}

Table 4 shows the respondents' level of awareness regarding $\mathrm{CR}$ and majority were unaware (57.0\%) about CR among CHD patients.

TABLE 4 - Respondents' Level of Awareness Regarding CR

\begin{tabular}{|l|l|}
\hline \multicolumn{2}{|l|}{$\mathrm{n}=100$} \\
\hline Awareness Level & Frequency/Percent \\
\hline Unaware $(<57.0 \%)$ & 57.0 \\
\hline Aware $(\geq 57.0 \%)$ & 43.0 \\
\hline Total & 100.0 \\
\hline \multicolumn{2}{|l|}{ Median score of overall Awareness=17 (IQR $=14.0-19.75)$} \\
\hline
\end{tabular}

Table 5 shows the level of awareness and socio-demographic characteristics were significantly associated with age $(\mathrm{p}=0.007)$ and educational status $(\mathrm{p}=0.013)$ at $\mathrm{p}$ value $<0.05$.

TABLE 5- Association between Level of Awareness regarding CR and Socio- demographic Characteristics

\begin{tabular}{|l|l|l|l|l|}
\hline \multicolumn{2}{|l}{} & \multicolumn{2}{|}{$\mathrm{n}=100$} \\
\hline $\begin{array}{l}\text { Socio-demographic } \\
\text { characteristic }\end{array}$ & $\begin{array}{l}\text { Level of Awareness } \\
\text { regarding CR }\end{array}$ & $\begin{array}{l}\alpha^{2} \\
\text { Value }\end{array}$ & $\begin{array}{l}\text { P } \\
\text { Value }\end{array}$ \\
\hline & $\begin{array}{l}\text { Aware } \\
\text { No. (\%) }\end{array}$ & $\begin{array}{l}\text { Unaware } \\
\text { No. (\%) }\end{array}$ & & \\
\hline Age in years & & \\
\hline
\end{tabular}

\begin{tabular}{|c|c|c|c|c|}
\hline$<54$ & $29(55.8)$ & $23(44.2)$ & 7.20 & 0.007 \\
\hline 54 and above & $14(29.2)$ & $34(70.8)$ & & \\
\hline \multicolumn{5}{|l|}{ Gender } \\
\hline Male & $24(43.6)$ & $31(56.4)$ & 0.02 & 0.887 \\
\hline Female & $19(42.2)$ & $26(57.8)$ & & \\
\hline \multicolumn{5}{|l|}{ Residence } \\
\hline Urban & $21(40.4)$ & $31(59.6)$ & 0.302 & 0.582 \\
\hline Rural & $22(45.8)$ & $26(54.2)$ & & \\
\hline \multicolumn{5}{|l|}{ Living Status } \\
\hline Living Single & $8(33.3)$ & $16(66.7)$ & & \\
\hline $\begin{array}{l}\text { Living with } \\
\text { Family }\end{array}$ & $35(46.1)$ & $41(53.9)$ & 1.20 & 0.273 \\
\hline \multicolumn{5}{|l|}{ ^Ethnicity } \\
\hline Brahmin/Chhetri & $26(44.1)$ & $33(55.9)$ & 0.067 & 0.796 \\
\hline Janajati/Dalit & $17(41.5)$ & $24(58.5)$ & & \\
\hline \multicolumn{5}{|l|}{ Religion } \\
\hline Hindu & $36(42.9)$ & $48(57.1)$ & 0.004 & 0.947 \\
\hline Non-Hindu & $7(43.8)$ & $9(56.2)$ & & \\
\hline \multicolumn{5}{|l|}{ Type of Family } \\
\hline Nuclear & $20(40.8)$ & $29(59.2)$ & & \\
\hline Joint Family & $23(45.1)$ & $28(54.9)$ & 0.187 & 0.665 \\
\hline \multicolumn{5}{|l|}{ Educational status } \\
\hline Literate & $31(53.4)$ & $27(46.6)$ & 6.151 & 0.013 \\
\hline Illiterate & $12(28.6)$ & $30(71.4)$ & & \\
\hline \multicolumn{5}{|l|}{ Occupation } \\
\hline $\begin{array}{l}\text { Farming \& } \\
\text { Housework }\end{array}$ & $24(42.9)$ & $32(57.1)$ & 0.001 & 0.974 \\
\hline Service \& Business & $19(43.2)$ & $25(56.8)$ & & \\
\hline \multicolumn{5}{|c|}{ Significance level $<0.05, \star$ Pearson chi square } \\
\hline
\end{tabular}

And Table 6 also represented that level of awareness and disease related variables was highly significant with duration of treatment $(\mathrm{p}=0.039)$ and participation in awareness program $(\mathrm{p}=0.001)$ at $\mathrm{p}$ value $<0.05$.

TABLE 6 - Association between Level of Awareness regarding CR and Disease Related Variables

\begin{tabular}{|c|c|c|c|c|}
\hline & & & & $\mathrm{n}=100$ \\
\hline $\begin{array}{l}\text { Disease related } \\
\text { variables }\end{array}$ & $\begin{array}{l}\text { Level of } \\
\text { regarding }\end{array}$ & areness & $\begin{array}{l}\alpha^{2} \\
\text { Value }\end{array}$ & P Value \\
\hline & $\begin{array}{l}\text { Aware } \\
\text { No. (\%) }\end{array}$ & $\begin{array}{l}\text { Unaware } \\
\text { No. (\%) }\end{array}$ & & \\
\hline Clinical Diagno & & & & \\
\hline Angina \& IHD & $33(45.8)$ & $39(54.2)$ & 0.842 & 0.359 \\
\hline $\begin{array}{l}\text { Myocardial } \\
\text { Infarction }\end{array}$ & $10(35.7)$ & $18(64.3)$ & & \\
\hline Duration of Tre & & & & \\
\hline$<1$ year & $24(54.5)$ & $20(45.5)$ & 4.273 & 0.039 \\
\hline$\geq 1$ years & 19(33.9) & $37(66.1)$ & & \\
\hline Mode of Treatm & & & & \\
\hline Invasive & $21(42.9)$ & $28(57.1)$ & 0.001 & 0.977 \\
\hline
\end{tabular}




\begin{tabular}{|l|l|l|l|l|}
\hline Non- invasive & $22(43.1)$ & $29(56.9)$ & & \\
\hline \multicolumn{5}{|l|}{ Regular intake of hypertensive medication } \\
\hline Yes & $35(79.5)$ & $9(20.5)$ & 1.638 & 0.201 \\
\hline No & $15(65.2)$ & $8(34.8)$ & & \\
\hline Co-morbidity & $36(42.9)$ & $48(57.1)$ & 0.004 & 0.947 \\
\hline Present & $7(43.8)$ & $9(56.2)$ & & \\
\hline Absent & $10(22.7)$ & $34(77.3)$ & 13.175 & 0.001 \\
\hline Participated in CR program & $33(58.9)$ & $23(41.1)$ & & \\
\hline Yes & No & & \\
\hline Significance level<0.05, ${ }^{\circ}$ Pearson chi-square \\
\hline
\end{tabular}

\section{Discussion}

Findings of this study suggest that the mean age of respondents was 53.23 years in this study. While different studies reported slightly higher mean age such as in Canada ${ }^{9}$ (64.6) and in China ${ }^{10}$ (62.51), which might be due to the setting of study. In this study, regarding socio-demographic characteristics, majority of the respondents were male $(55.0 \%)$, resided in urban $(52.0 \%)$, living with family $(76.0 \%)$, Hindu $(84.0 \%)$, belonged to joint family $(51.0 \%)$, and literate $(58.0 \%)$. This finding was consistent with a study findings reported that the seventy two percentages of the respondents were male, residing in urban area $(53.1 \%)$, living with family $(92.5 \%)$, Hindu by religion $(85.0 \%)$, and literate $(63.4 \%){ }^{11}$

Regarding disease related variables, majority of respondents had Angina Pectoris (47.0\%) with duration of treatment as 1 year or above $(56.0 \%)$, continuous medical management as a mode of treatment $(51.0 \%)$, presence of highest co morbidities were hypertension $(71.7 \%)$ and not participating in CR program (56.0\%). This findings was consistent with a study done in Nepal. ${ }^{12}$ Similarly, another study conducted in Spain reported angina pectoris is the most common diagnosis among CHD patient. ${ }^{13}$ Fifty seven percent of the respondents were unaware about CR. This finding was consistent with a study done in China reported by Zhou (2017) that level of awareness was low $(52.69 \%){ }^{8}$

Similarly, the significant associated factors between level of awareness regarding $\mathrm{CR}$ and selected variables were age $(\mathrm{p}=0.007)$, educational status $(\mathrm{p}=0.013)$, duration of treatment of more than or equal to one year $(\mathrm{p}=0.039)$ and less participation in awareness programs $(\mathrm{p}=0.001)$. This finding was supported by a study done in China which found that older CHD patients were significantly associated with low level of awareness with CR program. ${ }^{8}$

\section{Conclusion}

Our study found that patient's awareness on CR was low, especially for fifty four and above aged group, illiterate CHD patients, those receiving treatment for more than and equal to one years of duration of treatment and those that didn't participate in awareness program. Hence, health care professionals including nurses should organize \& promote CR program and strengthen the counseling program to enhance their awareness level as well as for improving the quality of life.

\section{Limitations}

It is hospital based study and sampling might also have affected the result of this study which limits the generalizability of the findings and it does not truly represent all CHD population of Nepal.

\section{References}

1. Kayaniyii S, Ardern C, Winstanley J, et al. Degree and correlates of cardiac knowledge and awareness among cardiac inpatients. Patient Educ Couns 2009; 75(1):99-107. Doi: 10.1016/j.pec.2008.09.005.

https://doi.org/10.1016/j.pec.2008.09.005

2. Nekouei ZK, Yousefy A, Doost HTN, et al. Structural Model of psychological risk and protective factors affecting on quality of life in patients with coronary heart disease: A psychocardiology model. J Res Med Sci 2014;19(2):90-8.

3. Stafford L, Berk M, Reddy P, et al. Comorbid depression and health-related quality of life in patients with coronary artery disease. J Psychosom Res.2007;62(4):401-10.

https://doi.org/10.1016/j.jpsychores.2006.12.009

4. Hofer S, Saleem A, Stone J, et al. The MacNew Heart Disease Health- Related Quality of Life Questionnaire in patients with angina and patients with ischemic heart failure. Value Health. 2012 Jan;15(1):143-50.

https://doi.org/10.1016/j.jval.2011.07.003

5. Acharya P, Adhikari RR, Bhattarai J, et al. Delayed presentation of acute coronary syndrome:A challenge in it's earlymanagment. J Nepal Med Assoc 2009;48(173):1-4. https://doi.org/10.31729/jnma.173

6. Vaidya A, Pokharel PK, Nagesh S, et al. Prevalence of coronary heart disease in the urban adult males of eastern Nepal: a population-based analytical cross-sectional study. Indian Heart J 2009;61(4):341-7.

7. Schlitt A, Wischmann P, Wienke A, et al. Rehabilitation in Patients with Coronary Heart Disease- participation and its effect on prognosis. Dtsch Arztebl Int 2015; 112: 527-34. https://doi.org/10.3238/arztebl.2015.0527

8. Zhou Y, Li J, Du S, et al. Cardiac rehabilitation knowledge in patients with Coronary heart disease in Baoding city of China: A cross- sectional study. International Journal of Nursing Sciences 2017 (4):24-28.

https://doi.org/10.1016/j.ijnss.2016.12.011

9. Norris CM, Ghali WA, Gallbraith PD, et al. Knudtson ML. Women with coronary artery disease report worse healthrelated quality of life outcomes compared to men. Health Qual Life Outcomes. 2004;2:1-11. https://doi.org/10.1186/1477-7525-2-1

10. Shrestha R, Shrestha S, Adhikari B, et al. Health-Related Quality of Life and Behavioural Risk Factors among Coronary Heart Disease Patients in a Tertiary Hospital. Int J Health Sci Res. 2015; 5(11):211-217.

11. Shrestha R \& Shrestha S. Health-Related Quality of Life of Patients with Coronary Heart Disease Attending a Cardiac Care Centre in Kathmandu. Journal of Institute $\mathrm{f}$ Medicine. 2015; 37(1):4-10. https://doi.org/10.1016/j.jacc.2015.06.529

12. Shrestha R. \& Shrestha S. Effectiveness of Educational Intervention on Life Style Management among Coronary Heart Disease Patinets Attending a Cardiac Care Centre in Kathmandu. Journal of Institute of Medicine 2016; 38(1):20-25.

13. Failde II, Soto MM. Changes in health related quality of life 3 months after an acute coronary syndrome. BMC Public health. 2006;6(18):1-10. https://doi.org/10.1186/1471-2458-6-18 